\title{
Effect of Crop Establishment Methods and Nitrogen Management on Growth and Yield of Rice
}

\author{
Polagani Nagarjuna ${ }^{1}$, B. Venkateswarlu ${ }^{2}$, Sreerekha, M. ${ }^{3}$, P.R.K. Prasad ${ }^{4}$ and \\ Jayalalitha, K. ${ }^{5}$
}

\author{
${ }^{1}$ Department of Agronomy, Agricultural College, Bapatla, Andhra Pradesh, India \\ ${ }^{2}$ Department of Agronomy, Agricultural College, Bapatla, Andhra Pradesh, India \\ ${ }^{3}$ Department of Agronomy (Water Management), APGC, Lam, Guntur, Andhra Pradesh, India \\ ${ }^{4}$ University Head (SSC\&AC), ARS, Amarvathi, Guntur, Andhra Pradesh, India \\ ${ }^{5}$ Department of Crop Physiology, Agricultural College, Bapatla, Andhra Pradesh, India
}

*Corresponding author: pol.nag143@gmail.com (ORCID ID: 0000-0002-3319-6869)

Paper No. 897

Received: 14-02-2021

Revised: 22-05-2021

Accepted: 08-06-2021

\begin{abstract}
A field experiment entitled "Effect of Crop Establishment Methods and Nitrogen Management on Growth and Yield of Rice" was conducted during the kharif season of 2019 and 2020 at the College Farm, Bapatla. The experiment was laid out in strip-plot design with three replications. The results revealed that among crop establishment methods, conventional tillage registered highest plant growth parameters at harvest like plant height (125.6 and $125.9 \mathrm{~cm})$, number of tillers $\mathrm{m}^{-2}(423.6$ and 426.9$)$, plant dry matter (13304 and $13443 \mathrm{~kg} \mathrm{ha}^{-1}$ ) and yield attributes i.e. the number of panicles $\mathrm{m}^{-2}$ (302.6 and 305.3), number of grains panicle ${ }^{-1}$ (219.3 and 225.3), grain (5870 and $5916 \mathrm{~kg} \mathrm{ha}^{-1}$ ) and straw yield (8049 and $8000 \mathrm{~kg} \mathrm{ha}^{-1}$ ) and was found statistically at par with dry seeding on puddled soil and significantly superior over rest of the treatments. Among nitrogen management, growth parameters at harvest i.e. plant height (125.9 and $128.0 \mathrm{~cm}$ ), number of tillers $\mathrm{m}^{-2}\left(427.2\right.$ and 429.3), plant dry matter $\left(12390\right.$ and $\left.12503 \mathrm{~kg} \mathrm{ha}^{-1}\right)$ and yield parameters i.e. the number of panicles $\mathrm{m}^{-2}$ (284.9 and 289.6), number of grains panicle ${ }^{-1}$ (210.4 and 215.8), grain (5650 and $5699 \mathrm{~kg} \mathrm{ha}^{-1}$ ) and straw yield (7783 and $7526 \mathrm{~kg} \mathrm{ha}^{-1}$ ) the highest were recorded with the application of 50\% STBN through fertilizer $+50 \% \mathrm{~N}$ through cured poultry manure $\left(\mathrm{N}_{5}\right)$, which was found statistically at par with $75 \%$ STBN through fertilizer $+25 \% \mathrm{~N}$ through cured poultry manure $\left(\mathrm{N}_{4}\right)$ and significantly superior over other treatments.

\section{HIGHLIGHTS}

( Conventional tillage and dry seeding on puddled soil recorded the highest growth parameters, yield attributes and yield. While, significantly the lowest value of growth parameters, yield attributes and yield were recorded under minimum tillage.

0 Among the nitrogen management, the highest growth, yield attributes and yield were recorded by $50 \%$ STBN through fertilizer along with $50 \% \mathrm{~N}$ through cured poultry manure.
\end{abstract}

Keywords: Crop establishment methods, Nitrogen, Poultry manure, FYM, Yield and Rice

Rice is the main staple food crop of India, covering an area of about $43.79 \mathrm{~m}$ ha with the total production and productivity of $112.91 \mathrm{~m} \mathrm{t}$ and $2.57 \mathrm{t} \mathrm{ha}^{-1}$ respectively, during 2019-2020 (www.indiastat.com 2019-20). Transplanting of paddy seedlings is a common method of crop establishment in the irrigated rice systems of Asia but transplanting is labour intensive ( 25 persons ha $^{-1}$ day $\left.^{-1}\right)$. The preparation of land for transplanting paddy

How to cite this article: Nagarjuna, P., Venkateswarlu, B., Sreerekha, M., Prasad, P.R.K. and Jayalalitha, K. 2021. Effect of Crop Establishment Methods and Nitrogen Management on Growth and Yield of Rice. IJAEB, 14(2): 185-189.

Source of Support: None; Conflict of Interest: None 
(puddling) consumes about $20-40 \%$ of the total water required for growing of crop and subsequently poses difficulties in seed bed preparation for succeeding crop in rotation (Kumar et al. 2008).

Conservation agriculture technologies involve minimum soil disturbance, providing a soil cover through crop residues and dynamic crop rotations for achieving higher productivity and sustainability (Bhattacharyya et al. 2006). These factors demand a major shift from puddled transplanting to alternative methods of establishing rice. Consequently, several options of mechanical direct-seeding, direct seeding on puddled and transplanting under unpuddled/ non-flooded conditions have been developed and evaluated by researchers in collaborations with farmers.

The broadcast sowing/ drilling/ dibbling of dry seeds in soil is called DSR. Direct seedling of rice has more benefits as compared to traditional transplanting due to less drudgery and early maturity by 7 to 10 days with less water requirement. However, it offers many advantages such as more efficient water use, high tolerance to water deficit, less methane gas emission, reduced cultivation cost, prevent the formation of hard pan in sub-soil and minimizes labour input (Balasubramanian and Hill 2002). Minimum tillage or reduced tillage establishment is used widely for many crops around the world and this technology has potential to allow savings in time, energy, water and labour during rice establishment (Piggin et al. 2002).

Nitrogen is the major essential plant nutrient and key input for rice production and increased yield in rice growing countries. An increase of $70-80 \%$ increase in yield of rice could be obtained by the application of nitrogen fertilizer. The application of the organic fertilizers such as the farmyard manure and poultry manure could increase the soil organic matter contents which serve several advantages like conservation and slow release of nutrients, improve soil chemical and physical conditions and preservation of soil moisture that help for high production. A proper combination of both organic and inorganic fertilizers have better effects on crop growth, development and yield components of than alone.

\section{MATERIALS AND METHODS}

The field experiment was conducted during kharif season of 2019 and 2020 at the Agricultural College Farm, Bapatla. The soil of the experimental site was a sandy clay loam (sand $42.50 \%$, silt $18.21 \%$ and clay $39.29 \%$ ) with a bulk density of $1.22 \mathrm{~g} / \mathrm{cc}$ having $\mathrm{pH} 7.9, \mathrm{EC} 0.56 \mathrm{dsm}^{-1}$, low in organic carbon $(0.5 \%)$, available nitrogen $\left(250 \mathrm{~kg} \mathrm{ha}^{-1}\right)$, medium in phosphorus (39 $\left.\mathrm{kg} \mathrm{ha}^{-1}\right)$ and potassium $\left(440 \mathrm{~kg} \mathrm{ha}^{-1}\right)$. Rice variety "BPT-5204" was taken as the test variety. The experiment was laid out in strip-plot design with crop establishment methods in horizontal strip and nitrogen management in vertical strip with three replications. The main plot comprised four different crop establishment methods viz, Dry seeding on puddled soil $\left(\mathrm{T}_{1}\right)$, Reduced tillage $\left(\mathrm{T}_{2}\right)$, Minimum tillage $\left(\mathrm{T}_{3}\right)$ and Conventional tillage $\left(\mathrm{T}_{4}\right)$; as horizontal strip treatments. Five nitrogen management treatments to rice viz.,100\% STBN through fertilizer $\left(\mathrm{N}_{1}\right), 75 \%$ STBN through fertilizer $+25 \% \mathrm{~N}$ through FYM $\left(\mathrm{N}_{2}\right), 50 \%$ STBN through fertilizer $+50 \% \mathrm{~N}$ through FYM $\left(\mathrm{N}_{3}\right), 75 \%$ STBN through fertilizer $+25 \% \mathrm{~N}$ through Cured poultry manure $\left(\mathrm{N}_{4}\right)$ and 50\% STBN through fertilizer $+50 \%$ $\mathrm{N}$ through Cured poultry manure $\left(\mathrm{N}_{6}\right)$ as vertical strip treatments.

\section{RESULTS AND DISCUSSION}

\section{Crop Growth Parameters}

Plant growth parameters viz. plant height $(\mathrm{cm})$, number of tillers $\mathrm{m}^{-2}$, and plant dry matter $\left(\mathrm{g} \mathrm{m}^{-2}\right)$ were studied during the investigation (Table 1). All these characters were significantly influenced by both crop establishment methods and nitrogen management practices but not due to their interaction.

Among crop establishment methods, significantly higher values of plant growth parameters were observed in $\mathrm{T}_{4}$ treatment i.e. conventional tillage, which was on a par with $\mathrm{T}_{1}$ treatment viz. dry seeding on puddled soil. Significantly the lowest values of plant growth parameters were observed in $\mathrm{T}_{3}$ treatment i.e. minimum tillage. Treatment $\mathrm{T}_{2}$ was significantly superior over $\mathrm{T}_{3}$ treatment but was significantly lower to $T_{4}$ and $T_{1}$ treatments, which could be due to $T_{4}$ and $T_{1}$ have higher values of plant growth parameters compared to other methods, this might be due to lower weed competition and higher nutrient uptake by crop, which provided congenial conditions for growth and development of rice crop. 
Table 1: Growth characters of rice as influenced by crop establishment methods and nitrogen management during kharif, 2019-20 and 2020-21

\begin{tabular}{|c|c|c|c|c|c|c|}
\hline \multirow{2}{*}{ Treatments } & \multicolumn{2}{|c|}{ Plant height $(\mathrm{cm})$} & \multicolumn{2}{|c|}{ Number of tillers $\mathrm{m}^{-2}$} & \multicolumn{2}{|c|}{ Plant dry matter (kg ha $\left.{ }^{-1}\right)$} \\
\hline & 2020-21 & $2020-21$ & $2020-21$ & $2020-21$ & $2020-21$ & 2020-21 \\
\hline \multicolumn{7}{|l|}{ Tillage practices } \\
\hline $\mathrm{T}_{2}-$ Reduced tillage & 92.59 & 93.75 & 251.8 & 255.0 & 11974 & 12176 \\
\hline $\mathrm{T}_{3}-$ Minimum tillage & 88.15 & 90.43 & 223.8 & 229.3 & 11047 & 11320 \\
\hline S.Em \pm & 2.29 & 2.17 & 8.05 & 3.85 & 216.45 & 197.29 \\
\hline $\mathrm{CD}(\mathrm{p}=0.05)$ & 7.93 & 7.49 & 27.86 & 13.32 & 749.0 & 682.7 \\
\hline CV $(\%)$ & 9.28 & 8.67 & 11.19 & 5.29 & 6.85 & 6.13 \\
\hline \multicolumn{7}{|l|}{ Nutrient management } \\
\hline $\mathrm{N}_{4}-75 \% \mathrm{STBN}+25 \% \mathrm{PM}$ & 101.5 & 102.3 & 314.5 & 316.6 & 12958 & 13166 \\
\hline $\mathrm{N}_{5}-50 \% \mathrm{STBN}+50 \% \mathrm{PM}$ & 108.5 & 109.2 & 327.2 & 329.3 & 13866 & 14097 \\
\hline S.Em \pm & 2.95 & 2.80 & 7.44 & 6.74 & 348.84 & 338.98 \\
\hline $\mathrm{CD}(\mathrm{p}=0.05)$ & 9.62 & 9.14 & 24.27 & 21.98 & 1137.6 & 1105.5 \\
\hline CV (\%) & 10.68 & 10.05 & 9.25 & 8.28 & 9.87 & 9.43 \\
\hline
\end{tabular}

There was a continuous stagnation of water in the puddled situation in the treatments $\mathrm{T}_{4}$ and $\mathrm{T}_{1}$. This continuous flooding with water could result in better terrestrial weed suppression. Added to this, there was a incorporation of these weeds in to the soil during puddling which adds organic matter to the soil. Hence, these treatments, rice crop was grown under weed free situation. Under these conditions, more nutrients were available to rice crop that encouraged rice crop growth thereby exposing to more light resulting in higher photosynthesis and better translocation of photosynthates in puddled plots. This could be the possible reason for the increase in growth parameters (Sarker et al. 2007; Das et al. 2014; Ashish Kumar, 2017; Nahar et al. 2018; Deo et al.2019).

In case of nitrogen treatments, 50\% STBN through fertilizer with $50 \% \mathrm{~N}$ through cured poultry manure $\left(\mathrm{N}_{5}\right)$ treatment recorded the highest values compared to other treatments. However, it was on a par with the $75 \%$ STBN through fertilizer with $25 \%$ $\mathrm{N}$ through cured poultry manure $\left(\mathrm{N}_{4}\right)$ treatment followed by $50 \%$ STBN through fertilizer with $50 \% \mathrm{~N}$ through FYM $\left(\mathrm{N}_{3}\right)$ treatment. Whereas, $\mathrm{N}_{3}$ and $\mathrm{N}_{2}$ treatments were on a par with each other.
Significantly the lowest plant height was recorded with $100 \%$ STBN through fertilizer $\left(\mathrm{N}_{1}\right)$ treatment. Higher values of growth parameters recorded in poultry manure combination with inorganic nitrogen treatment might be due to its higher content of nitrogen that was readily available to the crop and combined use of organic sources along with inorganic nitrogen might have maintained the nitrogen status in soil throughout the crop growth resulting in quick vegetative growth (Jha et al. 2004; Umashankar et al. 2005; Hossaen et al. 2011). Tiller number increased with integration of organic and inorganic nitrogen sources than alone (chemical or organic nitrogen). This might be due to integration of chemical and organic sources provided enough nutrients. This ultimately influences the soil environment positively for plant growth and this favourable soil condition might have resulted into higher growth at all stages (Verma and Kaur 2016).

\section{Yield Attributes and Yield}

Data pertaining to number of panicls ${ }^{-1}$, number of grains panicle ${ }^{-1}$, grain and straw yield of rice significantly influenced by different crop establishment methods and nitrogen treatments 
during 2019-20 and 2020-21. With regard to yield attributes and yield, the interaction effect between crop establishment methods and nitrogen treatments was non significant. 1000 grain weight (g) was not significantly influenced by crop establishment methods and nitrogen treatments during both the year of experimentation are presented in Table 2.

Yield attributing parameters at harvest were observed significantly higher in conventional tillage than other crop establishment methods might be due to better environmental and eco-physiological conditions prevailed by less crop- weed competition for moisture and light and make better availability of nutrients for proper development of plant drymatter and yield attributing characters viz., productive tillers and filled grains per panicle which resulted in increased grain yield of rice (Kumar et al. 2016). It was also observed that dry seeding on puddled soil was on a par with conventional tillage which might be due to the fact that a dry seed was done on puddled soil and later the soil was converted into submerged conditions as the growth and development of plants increased similar to that of transplanting situation in conventional tillage (Singh et al. 2006).

Similarly, in the nitrogen management treatments significantly higher value of yield attributing parameters were recorded with the application of $50 \%$ STBN through fertilizer with 50\% $\mathrm{N}$ through cured poultry manure, which was however at par with $75 \%$ STBN through fertilizer with $25 \% \mathrm{~N}$ through cured poultry manure might be due to higher nitrogen content in poultry manure which is readily available as compared to other organic manures and chemical fertilizers. The poultry manure is acidic in nature which might have helped in increasing the availability of nutrients. Concentration of essential nutrients for plants in the poultry manure were higher and steady nutrient release compared to other organic manures such as FYM could make it to perform well (Parihar 2004; kumar et al. 2008; Meena et al. 2017). Where $\mathrm{N}_{3}$ and $\mathrm{N}_{2}$ were comparable with each other during 2019-20 and 2020-21. The lowest values were recorded with $100 \%$ STBN through fertilizer might be due to less availability of nutrients at critical stages of crop growth period (Aruna et al. 2012; Jyothi et al. 2015).

Table 2: Yield attributes and yield of rice as influenced by crop establishment methods and nitrogen management during kharif, 2019 and 2020

\begin{tabular}{|c|c|c|c|c|c|c|c|c|c|c|}
\hline \multirow[t]{2}{*}{ Treatments } & \multicolumn{2}{|c|}{$\begin{array}{l}\text { Number of } \\
\text { panicles } \mathrm{m}^{-2}\end{array}$} & \multicolumn{2}{|c|}{$\begin{array}{c}\text { Total no of grains } \\
\text { panicle }^{-1}\end{array}$} & \multicolumn{2}{|c|}{$\begin{array}{l}\text { Test weight } \\
\text { (g) }\end{array}$} & \multicolumn{2}{|c|}{$\begin{array}{l}\text { Grain yield } \\
\left(\mathrm{kg} \mathrm{ha}^{-1}\right)\end{array}$} & \multicolumn{2}{|c|}{$\begin{array}{l}\text { Straw yield } \\
\left(\mathrm{kg} \mathrm{ha}^{-1}\right)\end{array}$} \\
\hline & 2019-20 & 2020-21 & 2019-20 & 2020-21 & 2019-20 & 2020-21 & 2019-20 & 2020- 21 & 2019-20 & 2020- 21 \\
\hline $\begin{array}{l}\mathrm{T}_{1} \text { - Dry seeding on puddled } \\
\text { soil }\end{array}$ & 261.1 & 267.3 & 195.4 & 200.8 & 15.51 & 15.12 & 5362 & 5376 & 7161 & 7248 \\
\hline $\mathrm{T}_{2}-$ Reduced tillage & 207.9 & 210.6 & 164.4 & 169.9 & 15.27 & 14.76 & 4980 & 4992 & 6644 & 6784 \\
\hline $\mathrm{T}_{4}$ - Conventional tillage & 272.6 & 275.4 & 199.3 & 205.3 & 15.60 & 15.39 & 5370 & 5416 & 7343 & 7484 \\
\hline S.Em \pm & 5.52 & 5.08 & 3.52 & 3.21 & 0.59 & 0.53 & 115.8 & 102.3 & 123.3 & 119.5 \\
\hline $\mathrm{CD}(\mathrm{p}=0.05)$ & 19.11 & 17.57 & 12.18 & 11.12 & NS & NS & 401 & 354 & 427 & 413 \\
\hline CV $(\%)$ & 9.24 & 8.36 & 7.78 & 6.89 & 14.89 & 13.75 & 8.96 & 7.85 & 6.94 & 6.60 \\
\hline $\mathrm{N}_{3}-50 \% \mathrm{STBN}+50 \% \mathrm{FYM}$ & 223.7 & 226.3 & 169.6 & 175.8 & 15.29 & 14.45 & 4800 & 4867 & 6860 & 6952 \\
\hline $\mathrm{N}_{4}-75 \% \mathrm{STBN}+25 \% \mathrm{PM}$ & 254.9 & 259.7 & 190.5 & 195.8 & 15.68 & 15.66 & 5400 & 5449 & 7208 & 7317 \\
\hline $\mathrm{N}_{5}-50 \% \mathrm{STBN}+50 \% \mathrm{PM}$ & 262.2 & 266.6 & 195.5 & 200.6 & 15.97 & 16.47 & 5521 & 5558 & 7995 & 8139 \\
\hline S.Em \pm & 10.08 & 10.01 & 6.85 & 6.55 & 0.45 & 0.72 & 210.3 & 197.7 & 194.6 & 209.0 \\
\hline $\mathrm{CD}(\mathrm{p}=0.05)$ & 32.89 & 32.64 & 22.34 & 21.36 & NS & NS & 686 & 645 & 634 & 681 \\
\hline $\mathrm{CV}(\%)$ & 15.09 & 14.74 & 13.54 & 12.56 & 10.11 & 16.88 & 14.6 & 13.6 & 9.79 & 10.33 \\
\hline
\end{tabular}




\section{CONCLUSION}

From the results of the present experiment conducted at a single location for two seasons, the following broad conclusions can be drawn that the highest growth parameters, yield attributes and yield resulted in conventional tillage. While, significantly the lowest value of growth parameters, yield attributes and yield were recorded under minimum tillage. Among the nitrogen management, the highest growth, yield attributes and yield were recorded by $50 \%$ STBN through fertilizer along with $50 \% \mathrm{~N}$ through cured poultry manure.

\section{REFERENCES}

Anup Das, R., Lal, D.P., Patel, R.G., Idapuganti, Jayanta Layek, S.V. Nagachan, P.K., Ghosh, Jurisandhya Bordoloi and Kumar, M. 2019. Effects of tillage and biomass on soil quality and productivity of low land rice cultivation by small scale farmers in North Eastern India. Soil E Tillage Res., 143: 50-58.

Aruna, P., Prabhakara Reddy, G. and Karuna Sagar, G. 2012. Effect of integrated nitrogen management on growth, yield, quality and post - harvest nutrient status of soil in aerobic rice (Oryza sativa L.). Crop Res., 43(1, 2 \& 3): 1-4.

Ashish, K. 2017. Effect of Crop Establishment Methods on Growth Yield and Water Productivity of Rice. Int. J. Agri. Sci., 8(1): 40-45.

Balasubramanian, V. and Hill, J. 2002. Direct wet seeding of rice in Asia. Emergence issues and strategic research needs for the $21^{\text {st }}$ century. In: Proc Annual Workshop of Directorate of Rice Research, Hyderabad.

Bhattacharyya, R., Singh, R.D., Chandra, S., Kundu, S. and Gupta, H.S. 2006. Effect of tillage and irrigation on yield and soil properties under rice (Oryza sativa) - wheat (Triticum aestioum) system on a sandy clay loam soil of Uttaranchal. Indian J. Agri. Sci., 76: 405-409.

Hossaen, M.A., Shamsuddoha, A.T.M., Paul, A.K., Bhuiyan M.S.I. and Zobaer, A.S.M. 2011. Efficacy of different organic manures and inorganic fertilizer on the yield and yield attributes of boro rice. The Agriculturists, 9(1\&2): 117-125.

Jha, S.K., Tripathi, R.S. and Malaiya, S. 2004. Influence of integrated nutrient management practices on growth and yield of scented rice (Oryza sativa L.). Annals of Agri. Res., New Series, 25(1): 159-161.

Jyothi, R.J. and Nalliah, D.S. 2015. Influence of integrated nutrient management practices on yield and yield attributes and economics of transplanted rice (Oryza sativa) in south zone of Tamil Nadu. Int. J. Inno. Res. Sci. Tech., 1(11): 462-466.

Kharia, K.S., Thind, H.S., Sharma, S. and Kumar, S. 2016. Long term effect of rice cultivation methods, tillage and rice straw management on chemo-enzymatic properties in wheat. Green Farm., 7(6): 1389-1393.
Kumar, V., Bellinder, R.R., Gupta, R.K., Malik, R.K. and Brainard, D.C. 2008. Role of herbicide-resistant rice in promoting resource conservation technologies in ricewheat cropping systems of India: A review. Crop Prot., 27: 290-301.

Kumar, S.G., Muthukrishnan, P., Ramaswamy, S. and Chandragiri, K.K. 2008. Effect of non-conventional system of cultivation with varied $\mathrm{N}$ levels on growth, yield and water management of rice (Oryza sativa L.). Madras Agri. J., 95(7-12): 343-352.

Deo, M., Chaudhary, M., Adhikari, B.B. and Kandel, B.P. 2019. Study of the effect of tillage, seed priming and mulching on direct seeded rice variety sukhadhan-5 in mid hills of Nepal. Azarian J. Agri., 6(3): 74-79.

Meena, H.N., Bohra, J.S., Meena, R.N., Arvindkumar, Kumar, A. and Jat, S.L. 2017. Influence of tillage and crop establishment methods on system productivity and economics in rice-wheat cropping system. Annals of Agri. Re., New Series, 38(1): 50-54.

Nahar, L., Sarker, A.B.S., Mahbub, M.M. and Akter. R. 2018. Effect of Crop Establishment Method and Nutrient Management on Yield and Yield Attributes of Short Duration T. Aman Rice. Bangladesh Agro. J., 21(1): 117-123.

Parihar, S.S. 2004. Physico-chemical properties of soil and grain yield of rice (Oryza sativa) as influenced by organic and inorganic sources of nutrients. Annals of Agri. Res., 25(3): 408-411.

Piggin, C.M, Gracia, C.O. and Janiya, J.D. 2002.Establishment of irrigated rice under zero and conventional tillage system in the Philippines in Proc. Int. workshop on herbicide resistance management and zero tillage in rice-wheat system, 4-6: 190-195.

Sarker, A.B.S., Rahman, M.B., Yasmeen, R., Islam, MA. and Islam, S.M.M. 2007. Effect of Crop Establishment Methods on the Performance of Boro Rice (Oryza sativa L.) in the Cooler Region under Light Texture Soil Condition. The Agriculturists, 5(1\&2): 95-100.

Singh, V.P., Singh, G., Singh, S.P., Kumar, A., Sharma, G., Singh, M.K., Mortimer, M. and Johnson, D.E. 2006. Effect of weed management and crop establishment methods on weed dynamics and grain yield of rice. Indian J. Weed Sci., 38(1\&2): 20-24.

Singh, G.R., Parihar and Chaure, N.K. 2001. Effect of poultry manure and its combination with nitrogen in rice-wheat cropping system. Indian Agriculturist, 45(3\&4): 235-240.

Ullah, S., Rahman, M.M., Nahar, U.A. and Ahmed, M.N. 2016. Soil test based inorganic fertilizer and integrated plant nutrition system for rice cultivation in Inceptisols of Bangladesh. The Agriculturists, 14(1): 33-42.

Verma, G. and Kaur, S. 2016. Effect of Nitrogen Levels Alone and In Combination with Farm Yard Manure, Potassium and Phosphorus on Grain Yield. Int. J. Agri. Sci., 8(47): 1974-1975. 
